Article

\title{
A Fast and Validated Reversed-Phase HPLC Method for Simultaneous Determination of Simvastatin, Atorvastatin, Telmisartan and Irbesartan in Bulk Drugs and Tablet Formulations
}

\author{
Hassan A. Alhazmi ${ }^{1, *}$, Ahmed M. Alnami ${ }^{1}$, Mohammed A. A. Arishi ${ }^{1}$, Raad K. Alameer ${ }^{1}$, \\ Mohammed Al Bratty ${ }^{1}$, Zia ur Rehman ${ }^{1,2}$, Sadique A. Javed ${ }^{1}$ and Ismail A. Arbab ${ }^{1,3}$ \\ 1 Department of Pharmaceutical Chemistry, College of Pharmacy, Jazan University, Jazan 45142, Saudi Arabia; \\ ahmed.alnoaimi@gmail.com (A.M.A.); sargo_4@hotmail.com (M.A.A.A.); \\ raadalameer@hotmail.com (R.K.A.); malbratty@jazanu.edu.sa (M.A.B.); ziaurrehman1@gmail.com (Z.u.R.); \\ sajaved@jazanu.edu.sa (S.A.J.); ismailupm2011@gmail.com (I.A.A.) \\ 2 Department of Pharmacy, IBMER, Mangalayatan University, 33rd Milestone, Beswan 202145, Aligarh, India \\ 3 Department of Chemistry, Faculty of Education, University of West Kordufan, El Nahud, \\ West Kordufan State, Sudan \\ * Correspondence: haalhazmi@jazanu.edu.sa; Tel.: +966-541433344
}

Received: 20 November 2017; Accepted: 8 December 2017; Published: 19 December 2017

\begin{abstract}
The aim of this study was to develop and validate a fast and simple reversed-phase HPLC method for simultaneous determination of four cardiovascular agents-atorvastatin, simvastatin, telmisartan and irbesartan in bulk drugs and tablet oral dosage forms. The chromatographic separation was accomplished by using Symmetry C18 column $(75 \mathrm{~mm} \times 4.6 \mathrm{~mm} ; 3.5 \mu)$ with a mobile phase consisting of ammonium acetate buffer $(10 \mathrm{mM} ; \mathrm{pH} 4.0)$ and acetonitrile in a ratio 40:60 $\mathrm{v} / \mathrm{v}$. Flow rate was maintained at $1 \mathrm{~mL} / \mathrm{min}$ up to $3.5 \mathrm{~min}$, and then suddenly changed to $2 \mathrm{~mL} / \mathrm{min}$ till the end of the run $(7.5 \mathrm{~min})$. The data was acquired using ultraviolet detector monitored at $220 \mathrm{~nm}$. The method was validated for linearity, precision, accuracy and specificity. The developed method has shown excellent linearity $\left(R^{2}>0.999\right)$ over the concentration range of $1-16 \mu \mathrm{g} / \mathrm{mL}$. The limits of detection (LODs) and limits of quantification (LOQs) were in the range of 0.189-0.190 and $0.603-0.630 \mu \mathrm{g} / \mathrm{mL}$, respectively. Inter-day and intra-day accuracy and precision data were recorded in the acceptable limits. The new method has successfully been applied for quantification of all four drugs in their tablet dosage forms with percent recovery within $100 \pm 2 \%$.
\end{abstract}

Keywords: reversed-phase HPLC; atorvastatin; simvastatin; telmisartan; irbesartan

\section{Introduction}

Atorvastatin (ATV) is chemically (3R,5R)-7-[2-(4-fluorophenyl)-3-phenyl-4-(phenylcarbamoyl)-5propan-2-ylpyrrol-1-yl] 3,5-dihydroxyheptanoic acid (Figure 1A), while simvastatin (SMV) is $\quad[(1 S, 3 R, 7 S, 8 S, 8 \mathrm{a} R)-8-[2-[(2 R, 4 R)-4$-hydroxy-6-oxooxan-2-yl]ethyl]-3,7-dimethyl-1,2,3,7,8,8ahexahydronaphthalen-1-yl]2,2-dimethylbutanoate (Figure 1B). Both ATV and SMV belong to the statins, which is a class of drugs that are used to lower blood cholesterol and triglyceride levels in the patients with cardiovascular complications and those at high risk for the development of atherosclerosis [1-3]. Statins exert their anti-hyperlipidemic effects through competitive inhibition of 3-hydroxy-3-methyl glutaryl coenzyme-A (HMG-CoA) reductase and hence inhibit a rate limiting step in biosynthesis of cholesterol. As a consequence, these drugs lower the risk of heart attack, stroke and related cardiac complications in individuals with coronary heart disease, type 2 diabetes and other cardiovascular conditions [4-6]. In addition to lipid lowering effect, these drugs also have been 
reported to possess anticancer [7,8], immunomodulatory [9], anti-inflammatory [9], anti-oxidant [10], anti-malarial [11] and antifungal [12] activities.

Telmisartan (TLN) is chemically, 2-[4-[[4-methyl-6-(1-methylbenzimidazol-2-yl)-2-propylbenzimidazol1-yl]methyl]phenyl]benzoic acid (Figure 1C) and irbesartan (IRB) is 2-butyl-3-[[4-[2-(2H-tetrazol-5-yl) phenyl]phenyl]methyl]-1,3-diazaspiro[4.4]non-1-en-4-one (Figure 1D). TLN and IRB are selective non-peptide angiotensin II receptor antagonists, used for the management of hypertension. These drugs act by selectively blocking the AT1 receptors in the rennin-angiotensin system, and administered as single or combined with other anti-hypertensive agents [13].

A<smiles>CC(C)c1c(C(=O)Nc2ccccc2)c(-c2ccccc2)c(-c2ccc(F)cc2)n1CC[C@H](O)C[C@H](O)C(=O)O</smiles>

C<smiles>CCCc1nc2c(C)cc(-c3nc4ccccc4n3C)cc2n1Cc1ccc(-c2ccccc2C(=O)O)cc1</smiles>

B<smiles>CCC(C)(C)C(=O)OC1C[C@H](C)C=C2C=CC(C)[C@H](CC[C@H]3CC(O)CC(=O)O3)C21</smiles>

D

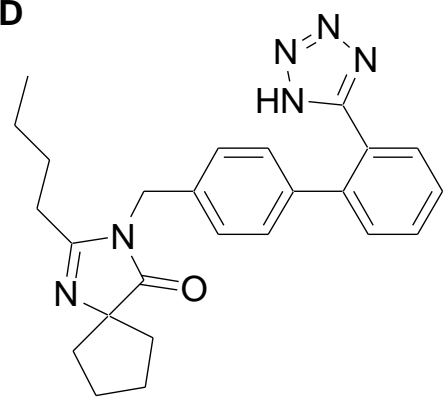

Figure 1. Chemical structures of (A) Atorvastatin (ATV); (B) Simvastatin (SMV); (C) Telmisartan (TLN) and (D) Irbesartan (IRB).

Literature survey reveals that a number of analytical methods have been developed for the determination of atorvastatin in single as well as in combined dosage forms by UV-spectrophotometry [14-17] and reversed-phase high performance liquid chromatography (RP-HPLC) [18-21] methods. Similarly, various analytical methods for the quantification of simvastatin using UV-spectrophotometry [22-24] and HPLC [25-27] in single and multidrug formulations were reported in the literature. The methods based on high performance thin layer chromatography have also been reported for the determination of simvastatin in bulk drugs and marketed formulations [28]. Various methods are also available for the analysis of telmisartan in single dosage forms as well as in combinations with other drugs by UV-spectrophotometry [29-31] and liquid chromatographic techniques such as HPLC [32,33], HPTLC [34,35]and supercritical fluid chromatography [36]. Furthermore, several methods for the quantification of irbesartan in bulk drug and single as well as combined formulations have been reported by using UV-spectrophotometric [36-39] and HPLC $[40,41]$ methods. Our study endeavors to develop and validate a reversed-phase HPLC method for simultaneous quantification of ATV, SMV, TLM and IRB in bulk drugs and their tablet dosage forms. To the extent of our knowledge, no analytical method based on reversed-phase HPLC have been reported so far, for the simultaneous estimation of the quaternary mixture containing ATV, SMV, TLM and IRB. Therefore, the current study was aimed to develop a rapid, simple and reproducible 
reversed-phase HPLC method for simultaneous quantification of the above cardiovascular drugs in bulk and tablet dosage forms and to validate the new method as per International Conference on Harmonization (ICH) method validation guidelines [42]. An attempt was made to choose a mobile phase that would be compatible with liquid chromatography-mass spectrometry, so that the developed method may be applicable for estimation of the test drugs in blood plasma samples during their pharmacokinetic monitoring. With the advent of combination therapy of anti-hyperlipidemic and anti-hypertensive agents, the proposed method will serve as a guide for their determination in API as well as in the formulations.

\section{Materials and Methods}

\subsection{Chemicals and Reagents}

The reference standards of atorvastatin, simvastatin, telmisartan and irbesartan were procured from Sigma Aldrich, Steinheim, Germany. Acetonitrile solvent (AR)-grade acetic acid, ammonium acetate, ammonium hydroxide and HPLC-grade acetonitrile were procured from Sigma Aldrich. Water (HPLC-grade) was prepared in our laboratory using Milli-Q water purification system (Millipore, Molsheim, France). Avapro ${ }^{\circledR}$ (Sanofi Aventis, Bridgewater, NJ, USA), Atorva ${ }^{\circledR}$ (Jazeera Pharmaceutical Industries, Riyadh, Saudi Arabia), Micardis ${ }^{\circledR}$ (Boehringer Ingelhein, Ingelhein am Rhein, Germany) and Zocor ${ }^{\circledR}$ (Merck Sharp \& Dohme Corporation, Whitehouse Station, NJ, USA) tablets consisting $75 \mathrm{mg}, 20 \mathrm{mg}, 80 \mathrm{mg}$ and $20 \mathrm{mg}$ of IRB, ATV (as calcium trihydrate), TLM and SMV respectively were purchased from the local community pharmacy.

\subsection{Instrumentation and Chromatographic Conditions}

The analysis was carried out by using Waters HPLC system (Waters Breeze 1525, Etten-Leur, The Netherlands) equipped with binary pump (Waters 1525), autosampler (Waters 2707) and UV-Visible detector (Waters 2489). The system was monitored by using Waters Breeze 2 LC solution software. HPLC separation was carried out on a Symmetry C18 column $(75 \mathrm{~mm} \times 4.6 \mathrm{~mm} ; 3.5 \mu \mathrm{m})$ maintained at ambient temperature with a mobile phase consisting of $10 \mathrm{mM}$ ammonium acetate buffer $(\mathrm{pH} 4)$ and acetonitrile with ratio 40:60 $\mathrm{v} / \mathrm{v}$. A volume of $20 \mu \mathrm{L}$ was injected and the flow rate was maintained at $1 \mathrm{~mL} / \mathrm{min}$ up to $3.5 \mathrm{~min}$, then suddenly increased to $2 \mathrm{~mL} / \mathrm{min}$ up to the end and all the analytes were monitored at $220 \mathrm{~nm}$, set as detection wavelength. The run time for all the analysis was $7.5 \mathrm{~min} .0 .77 \mathrm{~g}$ of ammonium acetate was accurately weighed and dissolved in $1 \mathrm{~L}$ of HPLC grade water. The $\mathrm{pH}$ of resulting solution was adjusted to 4.0 with the help of glacial acetic acid. The solution was then filtered through nylon filter $(0.45 \mu)$ to remove any suspended particles. Mobile phase was prepared by mixing ammonium acetate buffer and acetonitrile as an organic modifier in the ratio 40:60 $v / v$ and then sonicated for $10 \mathrm{~min}$ to degas.

\subsection{Preparation of Solutions}

\subsubsection{Standard Stock Solutions}

The standard stock solutions ( $1 \mathrm{mg} / \mathrm{mL}$ ) of IRB, ATV and SMV were prepared by dissolving an accurately weighed $10 \mathrm{mg}$ of each reference standards separately in $10 \mathrm{~mL}$ of methanol. The stock solution of TLM was prepared by dissolving $10 \mathrm{mg}$ of telmisartan standard in a mixture of methanol and acetonitrile $(60: 40 \mathrm{v} / \mathrm{v})$ in a $10-\mathrm{mL}$ volumetric flask.

\subsubsection{Working Standard Solutions}

The working standard solutions of IRB, ATV, TLM and SMV were obtained by diluting the respective standard stock solutions with a mixture of water and acetonitrile (1:1) to prepare calibration curve standards in the concentration range of $1-16 \mu \mathrm{g} / \mathrm{mL}$. 


\subsubsection{Sample Solutions}

As the combined formulation containing all the tested actives was not available in the market, the individual marketed tablet formulations were purchased for the analysis. Ten tablets of each drug were crushed and a weight equivalent to $10 \mathrm{mg}$ of ATV, SMV, TLM and IRB were transferred separately to $10 \mathrm{~mL}$ volumetric flasks and sonicated with methanol (for TLM, a mixture of methanol and acetonitrile, 60:40 v/v was taken) for $20 \mathrm{~min}$. The volume of each mixture was made and filtered through $0.45 \mu \mathrm{m}$ nylon syringe filter. The solutions were then diluted with a mixture of water and acetonitrile $(1: 1 \mathrm{v} / \mathrm{v})$ to get the final concentration of $10 \mu \mathrm{g} / \mathrm{mL}$ of each drug component.

\subsection{Method Validation}

The validation of the newly developed reversed-phase HPLC method was performed as per ICH guidelines of Validation of Analytical Procedure: Q2 (R1) [42]. The parameters of validation such as system suitability, linearity, limit of detection (LOD), limit of quantification (LOQ), precision, specificity, accuracy, recovery and solution stability were addressed.

\subsubsection{System Suitability}

To ensure the system performance, the suitability of the system was determined before and during analysis of unknown samples. Number of theoretical plates, retention time, peak separation (resolution), tailing factor and percent relative standard deviation (\%RSD) of area were assessed by injecting six replicates of standard solution. The system was considered to be suitable for the analysis when number of theoretical plates more than 2000, the tailing factor less than 2.0 and the \%RSD of the area of six replicate injections less than $2.0 \%$ were observed.

\subsubsection{Linearity}

The assessment of the detector response linearity was performed by analyzing a series of different concentrations of working standards (mixture of all analytes). The concentration range was selected at five point levels, viz. 1, 2, 4, 8 and $16 \mu \mathrm{g} / \mathrm{mL}$. All the solutions were injected into the system in six replicates and the corresponding area of each peak was recorded. Furthermore, the calibration curve was plotted by using the area of peaks of each component versus respective concentrations. The linearity of the method was calculated by regression analysis. A HPLC method is considered to be linear if it shows a correlation coefficient $\left(R^{2}\right)>0.999$.

\subsubsection{Precision and Accuracy}

The newly developed method was evaluated for its precision and accuracy by the analysis of the quality control samples containing all the analytes at three different concentrations, i.e., low quality control ( $2 \mu \mathrm{g} / \mathrm{mL}, \mathrm{LQC})$, medium quality control $(8 \mu \mathrm{g} / \mathrm{mL}, \mathrm{MQC})$ and high-quality control $(16 \mu \mathrm{g} / \mathrm{mL}$, HQC) levels. Intra-day precision and accuracy was assessed by analyzing six replicates of the sample and standard solutions in the same day at three different times, whereas inter-day precision and accuracy was established by performing same analysis over three successive days. The \%RSD of the observed peak area of each component at all concentration levels and the $\%$ recoveries were calculated.

\subsubsection{Limit of Detection and Limit of Quantification}

The LODs and LOQs for ATV, SMV, IRB and TLM were calculated by using the below mentioned Equations (1) and (2):

$$
\begin{aligned}
& L O D=\frac{3.3 \times S D}{s} \\
& L O Q=\frac{10 \times S D}{s}
\end{aligned}
$$


where, $S D$ represents the standard deviation corresponding to $Y$-intercept regression line and $s$ denotes the slope of the calibration curve.

\subsubsection{Specificity}

Specificity was carried out to determine the presence of interference due to co-eluting peaks (from blank) at the retention times of the analytes under investigation. To check the specificity of the proposed method, placebo solution was prepared in the same way as sample solution and injected in the HPLC system. Furthermore, the interference due to blank was detected by injecting the diluent separately. The chromatogram from the blank solution was compared with that of the sample solutions of bulk drugs as well as the tablet dosage forms.

\subsubsection{Solution Stability}

The stability of the sample and standard solutions was assessed by storing at different conditions including; $25^{\circ} \mathrm{C}$ (ambient condition) for $12 \mathrm{~h}$ (bench-top stability), $4{ }^{\circ} \mathrm{C}$ (refrigerator temperature) for 14 days and $-20^{\circ} \mathrm{C}$ for 30 days. At the end of each storage time the solutions were injected in the HPLC column and the results were compared with that of freshly prepared sample solutions. The stability analysis was performed using analytical solutions at MQC level.

\section{Results and Discussion}

\subsection{Method Development and Optimization}

The widespread use of lipid lowering drugs such as atorvastatin and simvastatin and anti-hypertensive agents such as telmisartan and irbesartan for the management of cardiovascular complications has stimulated our interest to develop a fast and simple analytical method for the simultaneous determination of the quaternary mixture of ATV, SMV, TLM and IRB in bulk and tablet formulations. The chromatographic parameters of the current method were optimized after various trials. The emphasis was laid on the selection of a volatile buffer, so that the method could easily be transferred to hyphenated techniques like LC-MS for bio-analysis of the tested drug products. Hence, ammonium acetate buffer which is compatible with LC-MS was selected for this study. In the optimization process, different buffer $\mathrm{pH}$, mobile phase compositions and two different detector wavelengths were tried. Based on the ionization of ATV, SMV, TLM and IRB two pH levels, acidic ( $\mathrm{pH} 4.0$ ) and alkaline ( $\mathrm{pH}$ 8.5) were selected. Mobile phase compositions of 50:50, 60:40, 70:30, 40:60 and 30:70 $v / v$ of ammonium acetate buffer and acetonitrile were tried. Poor separation and peak symmetry of the tested analytes were observed when a mobile phase with alkaline ammonium acetate buffer was used. At the ratios of 60:40 and 70:30 v/v ammonium-acetate buffer ( $\mathrm{pH} 8.5$ ) and acetonitrile in the mobile phase, only two drugs were eluted with satisfactory resolution in about 20 minutes run time at flow rate equal to $1 \mathrm{~mL} / \mathrm{min}$.

Different compositions of acidic ammonium-acetate buffer ( $\mathrm{pH} 4.0)$ and acetonitrile in the mobile phase were tried. A high-quality separation and symmetric peak shape for all the tested analytes was achieved with mobile phase made up of 40:60 $v / v$ ammonium-acetate buffer $(\mathrm{pH} 4.0)$ and acetonitrile at $1 \mathrm{~mL} / \mathrm{min}$ flow rate. With this composition, SMV was eluted at $9.1 \mathrm{~min}$, while the retention time for IRB, ATV and TLM were observed at 1.20, 1.82 and $2.40 \mathrm{~min}$, respectively. The retention time of SMV was reduced by using sudden change in flow rate, in which the flow rate was kept $1 \mathrm{~mL} / \mathrm{min}$ up to $3.5 \mathrm{~min}$, and then increased to $2 \mathrm{~mL} / \mathrm{min}$ until the end of the run. As a result, SMV was eluted at the retention time of about 6 min without affecting the retention times of other analytes and finally a runtime of $7.5 \mathrm{~min}$ was finalized for this analysis. Furthermore, the number of theoretical plates and tailing factor were also found to be in acceptable limits. The representative chromatogram of the finalized chromatographic conditions showing separation of peaks due to IRB, ATV, TLM and SMV is depicted in Figure 2. 


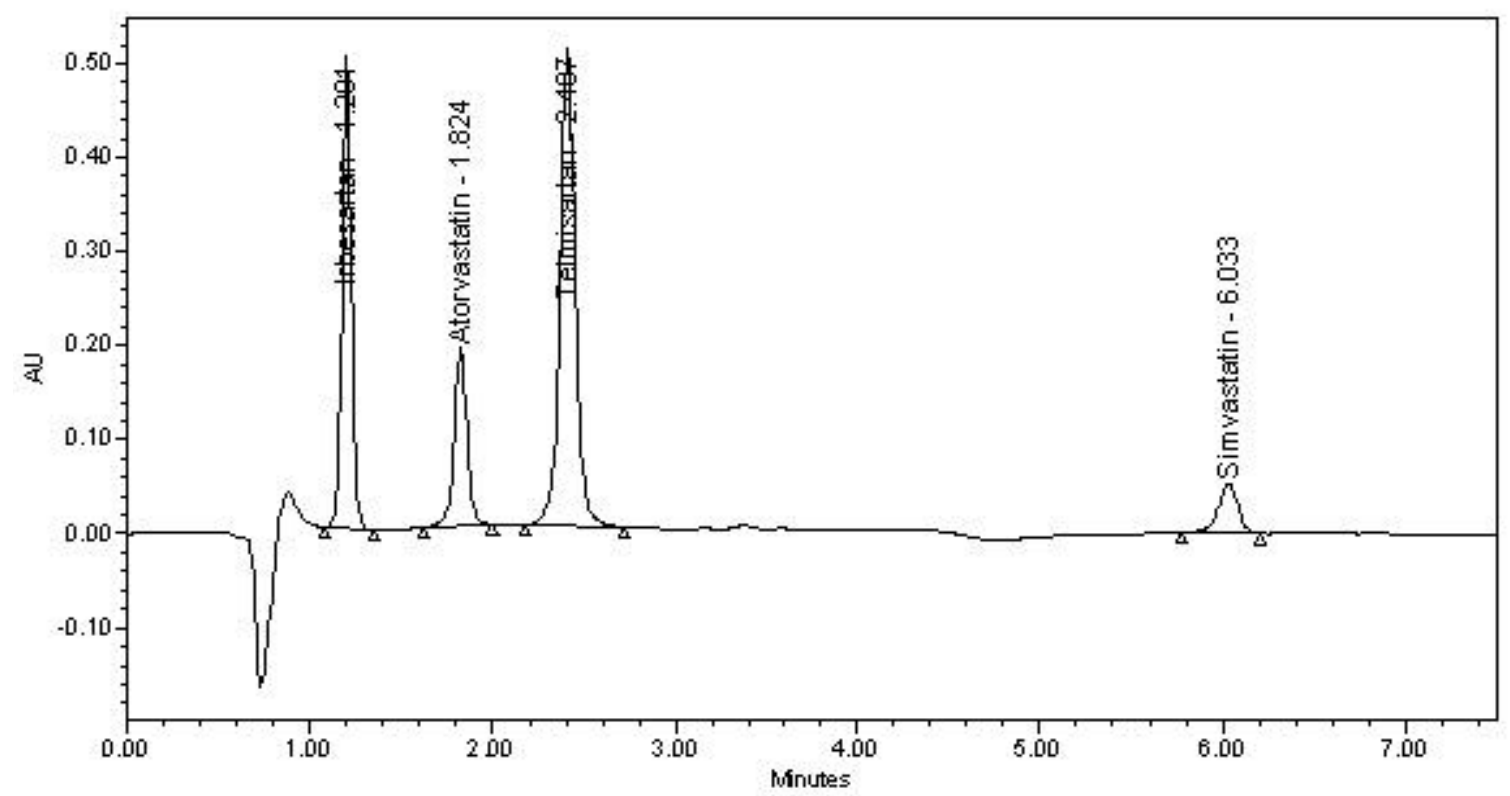

Figure 2. Chromatogram showing excellent separation between irbesartan, atorvastatin, telmisartan and simvastatin. Conditions: stationary phase, Symmetry C18 column; mobile phase, $10 \mathrm{mM}$ ammonium acetate buffer ( $\mathrm{pH} 4$ )-acetonitrile $(40: 60 \mathrm{v} / \mathrm{v})$; flow rate, $1 \mathrm{~mL} / \mathrm{min}$ up to $3.5 \mathrm{~min}$ then $2 \mathrm{~mL} / \mathrm{min}$; detection, UV $220 \mathrm{~nm}$.

\subsection{Method Validation}

The developed method was validated as per the criteria set by ICH guidelines. The validation was performed according to the parameters: linearity, precision and accuracy, system suitability, specificity and solution stability. The data obtained for each validation parameter were found well within the acceptance limits.

\subsubsection{System Suitability}

The number of theoretical plates, resolution, tailing factor and \%RSD of six replicate injections of the working standard solution were evaluated. The peaks due to all the analytes were found to be symmetrical as the observed tailing factors were less than 2 and the resolution between the drug peaks were satisfactory $(>2)$. The observed system suitability parameters of the present method were within the acceptable limits set by US Food and Drug Administration (FDA) regulations [43], which indicate the suitability of the system. The system suitability data of the present method are summarized in Table 1.

Table 1. Retention times, tailing factor, resolution, capacity factor and number of theoretical plate for atorvastatin (ATV), simvastatin (SMV), telmisartan (TLM) and Irbesartan (IRB) recorded by the developed HPLC method.

\begin{tabular}{ccccc}
\hline Parameters & IRB & ATV & TLM & SMV \\
\hline Retention time (min) & 1.20 & 1.82 & 2.40 & 6.03 \\
USP Tailing factor & 1.12 & 0.98 & 1.18 & 1.08 \\
USP Resolution & & 5.92 & 4.21 & 20.63 \\
USP Plate count & 2701 & 3621 & 4299 & 15122 \\
Percent RSD of peak area $(n=6)$ & 0.41 & 0.82 & 0.36 & 0.89 \\
\hline USP: United States Pharmacopeia.
\end{tabular}

USP: United States Pharmacopeia. 


\subsubsection{LOD and LOQ}

The values of LOD in the developed method were $0.189,0.190,0.189$ and $0.189 \mu \mathrm{g} / \mathrm{mL}$ for ATV, SMV, TLM and IRB respectively. The calculated LOQ values obtained were $0.603,0.604,0.603$ and $0.630 \mu \mathrm{g} / \mathrm{mL}$ for ATV, SMV, TLM and IRB respectively.

\subsubsection{Specificity}

The developed method was proven to have specificity as there was no significant interference from blank or placebo at the retention times of the analytes (ATV, SMV, TLM and IRB) observed. Furthermore, no carry-over effect was noticed throughout the analysis.

\subsubsection{Linearity}

The linearity of the developed method was assessed by preparing the calibration plot between the area of the peaks versus concentrations of IRB, ATV, TLM and SMV over the range of $1-16 \mu \mathrm{g} / \mathrm{mL}$ (Figure 3). Linear calibration plots were obtained for all the tested drugs and the mean correlation coefficients $\left(R^{2}\right)$ for individual analytes was achieved to be $>0.999$, which suggest that the proposed method is linear.
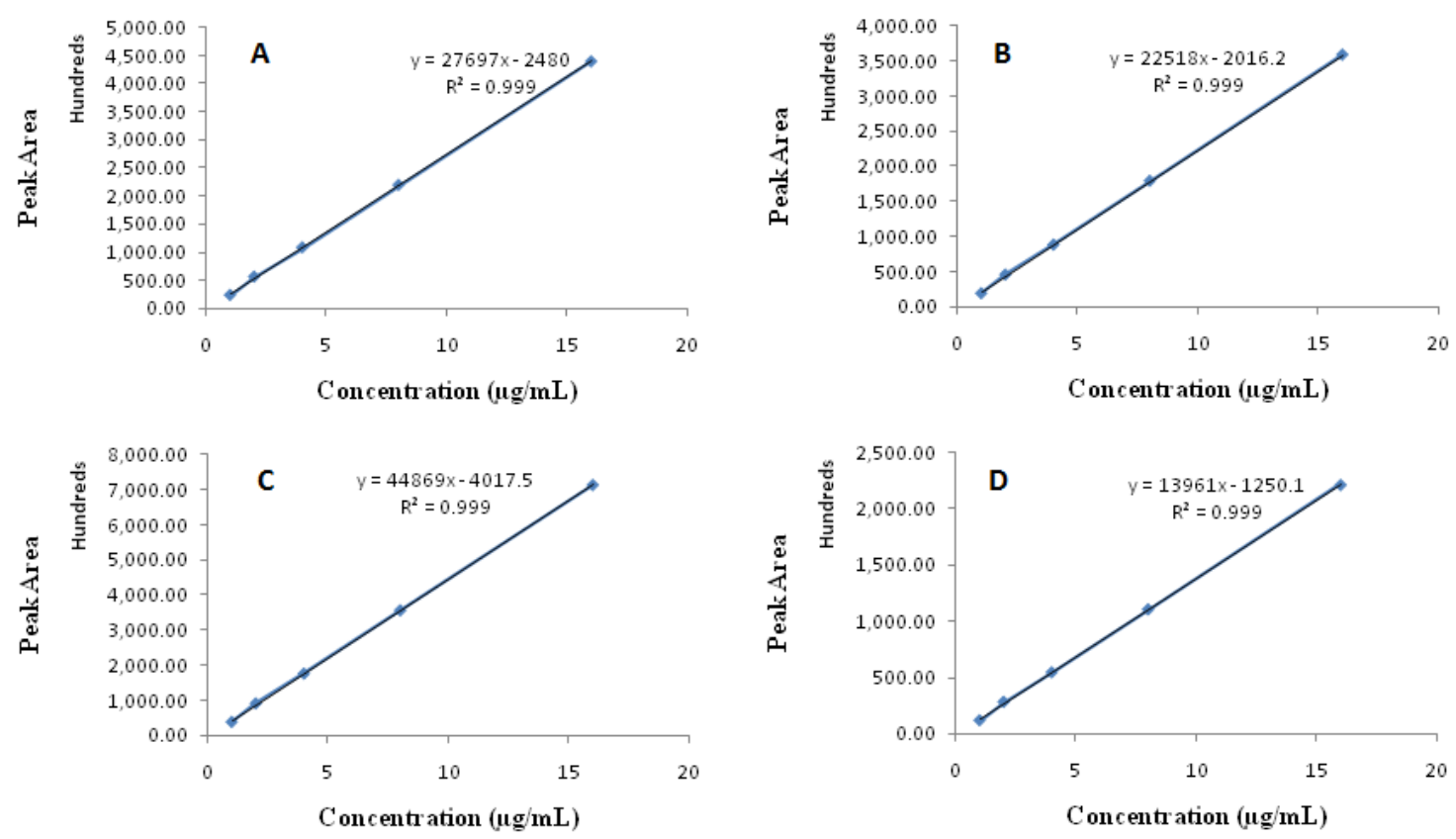

Figure 3. Calibration curve showing excellent linearity of the method: (A) Irbesartan; (B) Atorvastatin;

(C) Telmisartan and (D) Simvastatin.

\subsubsection{Precision and Accuracy}

The precision and accuracy data for both inter- and intra-day analysis of IRB, ATV, TLM and SMV in the quality control samples at three levels are depicted in Table 2. The inter-day precision values ranged from $1.35-2.06 \%, 0.97-1.61 \%, 0.36-1.39 \%$ and $0.38-1.52 \%$ for ATV, SMV, TLM and IRB respectively, while the intra-day precision (\%RSD of peak area) ranged from $1.39-2.10 \%, 0.46-1.41 \%$, $1.27-1.58 \%$ and $0.38-1.89 \%$ for ATV, SMV, TLM and IRB respectively. Similarly, the recovery values for all the tested analytes were within range of $98-102 \%$. The results of precision and accuracy were found to be within the acceptance limits and revealed that the new method is precise and accurate. 
Table 2. Precision and accuracy data of intra-day and inter-day samples for the proposed HPLC method, as carried out at three quality control levels for ATV, SMV, TLM and IRB.

\begin{tabular}{|c|c|c|c|c|c|}
\hline & $\begin{array}{c}\text { Concentration Levels } \\
(\mu \mathrm{g} / \mathrm{mL})\end{array}$ & ATV & SMV & TLM & IRB \\
\hline \multicolumn{6}{|c|}{ Intra-day Precision and Accuracy } \\
\hline \multirow{3}{*}{$\begin{array}{l}\% \text { RSD of peak area } \\
\text { (Average \% recovery) }\end{array}$} & 2 & $\begin{array}{c}2.10 \\
(101.99)\end{array}$ & $\begin{array}{c}1.41 \\
(100.75)\end{array}$ & $\begin{array}{c}1.39 \\
(102.14)\end{array}$ & $\begin{array}{c}1.89 \\
(100.41)\end{array}$ \\
\hline & 8 & $\begin{array}{c}1.61 \\
(100.21)\end{array}$ & $\begin{array}{c}0.46 \\
(100.30)\end{array}$ & $\begin{array}{c}1.58 \\
(100.26)\end{array}$ & $\begin{array}{c}0.38 \\
(100.75)\end{array}$ \\
\hline & 16 & $\begin{array}{c}1.39 \\
(100.07)\end{array}$ & $\begin{array}{c}1.30 \\
(100.32)\end{array}$ & $\begin{array}{c}1.265 \\
(100.34)\end{array}$ & $\begin{array}{c}1.07 \\
(100.83)\end{array}$ \\
\hline \multicolumn{6}{|c|}{ Inter-day Precision and Accuracy } \\
\hline \multirow{3}{*}{$\begin{array}{l}\% \text { RSD of peak area } \\
\text { (Average \% recovery) }\end{array}$} & 2 & $\begin{array}{c}2.06 \\
(101.95)\end{array}$ & $\begin{array}{c}1.52 \\
(102.78)\end{array}$ & $\begin{array}{c}1.39 \\
(102.02)\end{array}$ & $\begin{array}{c}1.52 \\
(102.64)\end{array}$ \\
\hline & 8 & $\begin{array}{c}1.60 \\
(100.32)\end{array}$ & $\begin{array}{c}0.97 \\
(99.99)\end{array}$ & $\begin{array}{c}0.69 \\
(99.98)\end{array}$ & $\begin{array}{c}0.38 \\
(101.38)\end{array}$ \\
\hline & 16 & $\begin{array}{c}1.35 \\
(100.10)\end{array}$ & $\begin{array}{c}1.61 \\
(101.34)\end{array}$ & $\begin{array}{c}0.36 \\
(100.80)\end{array}$ & $\begin{array}{c}1.07 \\
(101.20)\end{array}$ \\
\hline
\end{tabular}

2,8 and $16 \mu \mathrm{g} / \mathrm{mL}$ are low, medium and high-quality control sample concentrations, respectively; $n=3$.

\subsubsection{Solution Stability}

There was no stability related problem observed during the course of analysis under different conditions. The test and working standard solutions showed good stability at laboratory temperature for $12 \mathrm{~h}$ (average time of analysis), $4{ }^{\circ} \mathrm{C}$ (refrigerator temperature) for 14 days and $-20^{\circ} \mathrm{C}$ for 30 days. The stability of the analytical solutions was expressed as average percent recoveries, which were found to be in the range from $99.12-100.12 \%, 99.74-99.87 \%, 100.69-101.59 \%$ and $100.96-101.56 \%$ for ATV, SMV, TLM and IRB, respectively. The stability results in this study were found to be within the acceptable limits $( \pm 2 \%)$, which suggests that the sample and standard solutions can be evaluated under normal laboratory environment without any significant loss. The solution stability results are depicted in Table 3.

Table 3. Solution stability data at different storage conditions.

\begin{tabular}{clc}
\hline Analytes & Storage Conditions & Average \%Recovery * \\
\hline \multirow{3}{*}{ Atorvastatin } & Normal laboratory temperature $\left(25^{\circ} \mathrm{C}\right)$ for $12 \mathrm{~h}$ & 99.86 \\
& Refrigerator temperature $\left(4^{\circ} \mathrm{C}\right)$ for 14 days & 99.12 \\
& $-20{ }^{\circ} \mathrm{C}$ for 30 days & 100.12 \\
\hline \multirow{3}{*}{ Simvastatin } & Normal laboratory temperature $\left(25^{\circ} \mathrm{C}\right)$ for $12 \mathrm{~h}$ & 99.74 \\
& Refrigerator temperature $\left(4^{\circ} \mathrm{C}\right)$ for 14 days & 99.87 \\
& $-20{ }^{\circ} \mathrm{C}$ for 30 days & 99.84 \\
\hline \multirow{3}{*}{ Telmisartan } & Normal laboratory temperature $\left(25^{\circ} \mathrm{C}\right)$ for $12 \mathrm{~h}$ & 100.69 \\
& Refrigerator temperature $\left(4^{\circ} \mathrm{C}\right)$ for 14 days & 100.98 \\
& $-20{ }^{\circ} \mathrm{C}$ for 30 days & 101.59 \\
\hline \multirow{3}{*}{ Irbesartan } & Normal laboratory temperature $\left(25^{\circ} \mathrm{C}\right)$ for $12 \mathrm{~h}$ & 100.96 \\
& Refrigerator temperature $\left(4{ }^{\circ} \mathrm{C}\right)$ for 14 days & 101.56 \\
& $-20{ }^{\circ} \mathrm{C}$ for 30 days & 101.26 \\
\hline
\end{tabular}




\subsection{Application of the Developed Method in Determination of ATV, SMV, TLM and IRB in Tablet} Dosage Forms

The developed method was successfully applied for the quantification of IRB, ATV, TLM and SMV in their tablet formulations commercially available in the local market. Figure 4 shows the representative individual chromatograms of IRB, ATV, TLM and SMV in their tablet formulations. No variation in the runtime and other system suitability parameters were observed for all the component drugs. Furthermore, no interference from the placebo was noticed at the retention time of each analyte. The accuracy of this method in tablet formulation of each drug was determined by spiking method, where the recovery samples were prepared at 50\%, 100\% and 150\% levels of the targeted concentration $(10 \mu \mathrm{g} / \mathrm{mL})$. At each concentration level the recovery samples were prepared and injected in triplicate to the HPLC system in six replicates. The percent recovery of the amount of each drug component at every concentration level was calculated by determining their contents from the respective chromatograms. The average percent recovery of each analyte was found to be within $100 \pm 2 \%$. The calculated average percent recoveries for tablet formulations has been shown in Table 4 .

Table 4. Accuracy (recovery) data of ATV, SMV, TLM and IRB in tablet dosage forms.

\begin{tabular}{|c|c|c|c|c|}
\hline Analytes & $\begin{array}{c}\text { Recovery Sample } \\
\text { Concentrations }(\mu \mathrm{g} / \mathrm{mL})\end{array}$ & $\begin{array}{l}\text { Percentage of Targeted } \\
\text { Concentration }\end{array}$ & $\begin{array}{l}\text { Amount of Drugs } \\
\text { Recovered }(\mu \mathrm{g} / \mathrm{mL})\end{array}$ & $\begin{array}{l}\text { \%Recovery } \pm \\
\text { \%RSD }\end{array}$ \\
\hline \multirow{3}{*}{ Atorvastatin } & 5 & $50 \%$ & 5.02 & $100.42 \pm 0.57$ \\
\hline & 10 & $100 \%$ & 10.18 & $101.81 \pm 0.89$ \\
\hline & 15 & $150 \%$ & 15.14 & $100.98 \pm 0.73$ \\
\hline \multirow{3}{*}{ Simvastatin } & 5 & $50 \%$ & 4.94 & $98.86 \pm 1.09$ \\
\hline & 10 & $100 \%$ & 9.98 & $99.80 \pm 1.09$ \\
\hline & 15 & $150 \%$ & 14.95 & $99.67 \pm 1.10$ \\
\hline \multirow{3}{*}{ Telmisartan } & 5 & $50 \%$ & 5.06 & $101.38 \pm 1.58$ \\
\hline & 10 & $100 \%$ & 10.12 & $101.20 \pm 1.59$ \\
\hline & 15 & $150 \%$ & 15.16 & $101.07 \pm 1.59$ \\
\hline \multirow{3}{*}{ Irbesartan } & 5 & $50 \%$ & 5.07 & $101.50 \pm 0.38$ \\
\hline & 10 & $100 \%$ & 10.12 & $101.20 \pm 0.38$ \\
\hline & 15 & $150 \%$ & 15.15 & $101.05 \pm 0.39$ \\
\hline
\end{tabular}



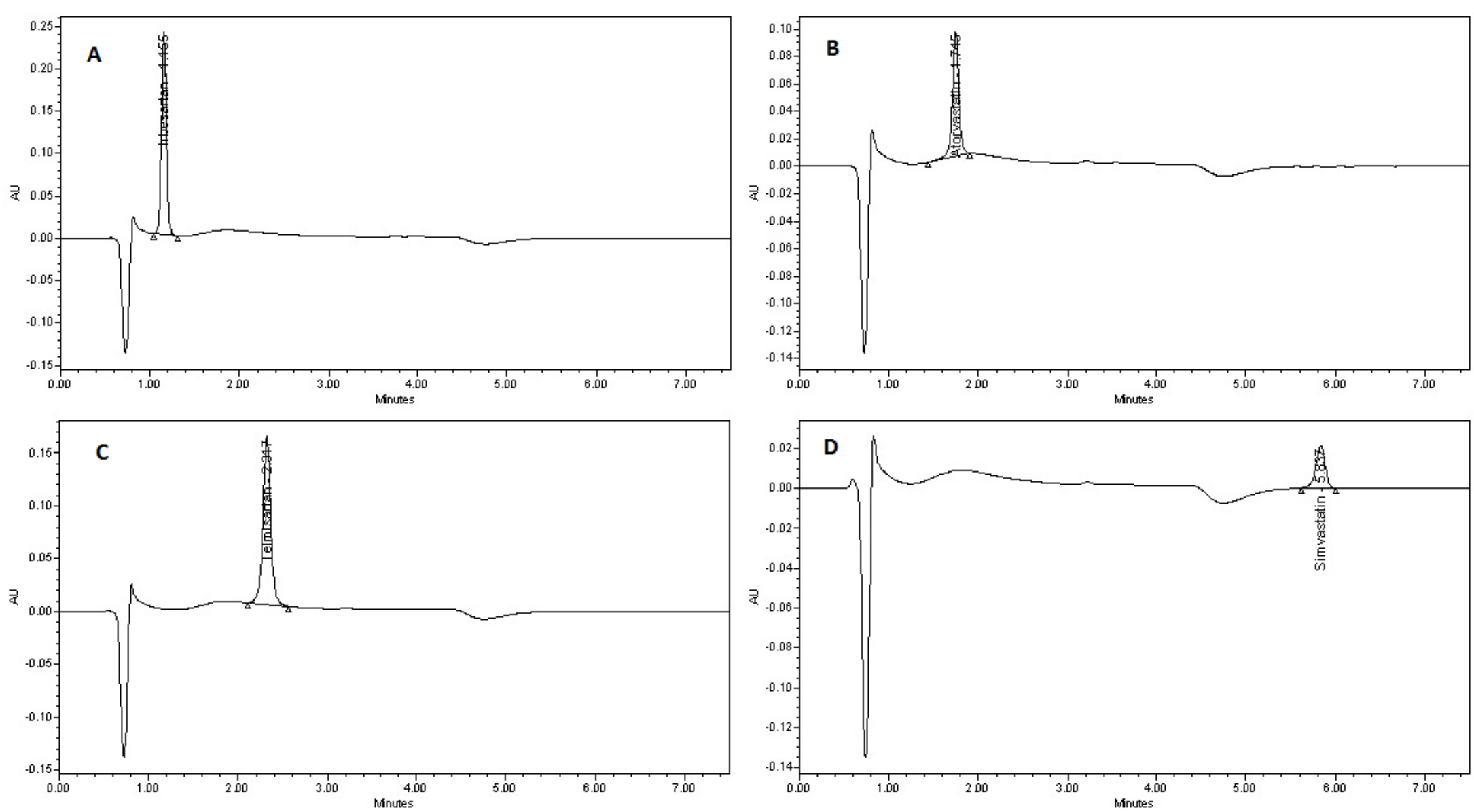

Figure 4. Representative chromatograms of individual analytes in tablet dosage forms. (A) Irbesartan; (B) Atorvastatin; (C) Telmisartan; and (D) Simvastatin. Conditions: stationary phase, Symmetry C18 column; mobile phase, $10 \mathrm{mM}$ ammonium acetate buffer ( $\mathrm{pH} 4)$-acetonitrile ( $40: 60 v / v)$; flow rate, $1 \mathrm{~mL} / \mathrm{min}$ up to $3.5 \mathrm{~min}$ then $2 \mathrm{~mL} / \mathrm{min}$; detection, UV $220 \mathrm{~nm}$. 


\section{Conclusions}

A fast and simple RP-HPLC method for the simultaneous quantification of atorvastatin, simvastatin, telmisartan and irbesartan has been successfully developed. The elution time for all the analytes was short $(7.5 \mathrm{~min})$ and found to have excellent peak shapes and acceptable system suitability parameters. The new method was validated as per ICH guidelines and it was found to be linear, precise, accurate and specific. All the analytes were stable in different storage conditions from laboratory temperature to $-20^{\circ} \mathrm{C}$. The developed method was applied successfully for the quantification and detection of ATV, SMV, TLM and IRB in their tablet oral dosage forms. The adaptability of this method to tablet formulations was proven by its excellent performance in terms of specificity and recovery for each drug component in the tablet samples. Therefore, the method may be utilized for day to day quality control (QC) analysis of IRB, ATV, TLM and SMV in bulk drugs or in their tablet dosage forms. The major advantage of the current method is that it is less time consuming and the ammonium acetate buffer used in mobile phase is compatible with LC-MS.

Acknowledgments: All the authors duly acknowledge the financial support given by Deanship of Scientific Research, Jazan University under the Fourth Future Scientist Program (FS4-039) to conduct this research work.

Author Contributions: H.A.A. and I.A.A. conceived and design the experiments, analyzed the data; A.M.A., M.A.A.A., R.K.A. and Z.u.R. performed the experiments; M.A. contributed reagents/materials/analysis tools and S.A.J. and Z.u.R. wrote the paper.

Conflicts of Interest: The authors declare no conflict of interest.

\section{References}

1. Law, M.R.; Wald, N.J.; Rudnicka, A.R. Quantifying effect of statins on low density lipoprotein cholesterol, ischaemic heart disease, and stroke: systematic review and meta-analysis. Bri. Med. J. 2003, 326, 1423-1429. [CrossRef] [PubMed]

2. Tamargo, J.; Caballero, R.; Gomez, R.; Nunez, L.; Vaquero, M.; Delpon, E. Lipid-lowering therapy with statins, a new approach to antiarrhythmic therapy. Pharmacol. Ther. 2007, 114, 107-126. [CrossRef] [PubMed]

3. Zhang, L.; Zhang, S.; Jiang, H.; Sun, A.; Zou, Y.; Ge, J. Effects of statin treatment on cardiac function in patients with chronic heart failure: a meta-analysis of randomized controlled trials. Clin. Cardiol. 2011, 34, 117-123. [CrossRef] [PubMed]

4. Lennernas, H. Clinical pharmacokinetics of atorvastatin. Clin. Pharmacokinet. 2003, 42, 1141-1160. [CrossRef] [PubMed]

5. Stancu, C.; Sima, A. Statins: Mechanism of action and effects. J. Cell. Mol. Med. 2001, 5, 378-387. [CrossRef] [PubMed]

6. Mansueto, P.; Vitale, G.; Seidita, A.; Guarneri, F.P.; Pepe, I.; Rinollo, C.; Rosa, S.D.; Rini, G.B.; Cillari, E.; Fede, G.D. Mevalonate pathway: Role of biphoslphonates and statins. Acta Med. Mediterr. 2011, 27, 97-107.

7. Ciofu, C. The statins as anticancer agents. Maedica 2012, 7, 337.

8. Nielsen, S.F.; Nordestgaard, B.G.; Bojesen, S.E. Statin use and reduced cancer related mortality. N. Engl. J. Med. 2012, 367, 1792-1802. [CrossRef] [PubMed]

9. Abeles, A.M.; Pillinger, M.H. Statins as anti-inflammatory and immunomodulatory agents: Afuture in rheumatologic therapy. Arthritis Rheumatol. 2006, 54, 393-407. [CrossRef] [PubMed]

10. Mason, R.P.; Walter, M.F.; Day, C.A.; Jacob, R.F. Active metabolite of atorvastatin inhibits membrane cholesterol domain formation by an antioxidant mechanism. J. Biol. Chem. 2006, 281, 9337-9345. [CrossRef] [PubMed]

11. Wong, R.P.M.; Davis, T.M.E. Statins as potential antimalarial drugs: Low relative potency and lack of synergy with conventional antimalarial drugs. Antimicrob. Agents Chemother. 2009, 53, 2212-2214. [CrossRef] [PubMed]

12. Galgóczy, L.; Nyilasi, I.; Papp, T.; Vágvölgyi, C. Statins as antifungal agents. World J. Clin. Infect. Dis. 2011, 1, 4-10. [CrossRef] 
13. Hafez, H.M.; Elshanawane, A.A.; Abdelaziz, L.M.; Kamal, M.M. Quantitative determination of three angiotensin-II-receptor antagonists in presence of hydrochlorothiazide by RP-HPLC in their tablet preparations. Iran. J. Pharm. Res. 2013, 12, 635-643. [PubMed]

14. Wani, T.A.; Khalil, N.Y.; Abdel-Rahman, H.M.; Darwish, I.A. Novel microwell-based spectrophotometric assay for determination of atorvastatin calcium in its pharmaceutical formulations. Chem. Cent. J. 2011, 5, 57. [CrossRef] [PubMed]

15. Bernard, S.; Mathew, M. Spectrophotometric method of estimation of atorvastatin calcium using sulfo-phospho-vanillin reaction. J. Appl. Pharm. Sci. 2012, 2, 150-154.

16. Maher, H.M.; Youssef, R.M.; Hassan, E.M.; El-Kimary, E.I.; Barary, M.A. Enhanced spectrophotometric determination of two antihyperlipidemic mixtures containing ezetimibe in pharmaceutical preparations. Drug Test. Anal. 2011, 3, 97-105. [CrossRef] [PubMed]

17. Al-Adl, S.M.; Abdel-Aziz, L.M.; Mohamed, M.A.M. Spectrophotometric determination of atorvastatin calcium and rosuvastatin calcium in bulk and dosage form using p-dimethyl aminobenzaldehyde. J. Appl. Pharm. 2017, 9, 233-239. [CrossRef]

18. Erturk, S.; Aktas, S.E.; Ersoy, L.; Ficicioglu, S. An HPLC method for the determination of atorvastatin and its impurities in bulk drug and tablets. J. Pharm. Biomed. Anal. 2003, 33, 1017-1023. [CrossRef]

19. Simionato, L.D.; Ferello, L.; Stamer, S.G.; Repetto, M.F.; Zubata, P.D.; Segall, A.I. A validated reversed-phase HPLC method for the determination of atorvastatin calcium in tablets. Austin Chromatogr. 2014, 1, 1-4.

20. Seshachalam, U.; Kothapally, C.B. HPLC analysis for simultaneous determination of atorvastatin and ezetimibe in pharmaceutical formulations. J. Liq. Chromatogr. Relat. Technol. 2008, 31, 714-721. [CrossRef]

21. Hassan, S.A.; Elzanfaly, E.S.; El-Zeany, S.B.; Salem, M.Y. Development and validation of HPLC and CE methods for simultaneous determination of amlodipine and atorvastatin in the presence of their acidic degradation products in tablets. Acta Pharm. 2016, 66, 479-490. [CrossRef] [PubMed]

22. Chavhan, V.; Reddy, K.; Ahhirao, K. Development of UV spectrophotometric methods and validation for estimation of simvastatin in bulk and tablet dosage form by absorbance maxima and area under the curve method. J. Appl. Pharm. 2014, 6, 55-64.

23. Balaji, S.; Sunitha, A. Development and validation of spectrophotometeric method for simultaneous determination of simvastatin and ezetimibe in tablet formulations. Pak. J. Pharm. Sci. 2010, 23, 375-378. [PubMed]

24. Sharma, S.; Manocha, N. Estimation of sitagliptin phosphate and simvastatin and validation of the proposed method in a combined marketed tablet dosage form by simultaneous equation method. Int. J. Curr. Pharm. Res. 2012, 4, 144-147.

25. Sreelakshmi, V.; Rao, U.M.V.; Pugazhendhy, S.; Shrivastava, S.K.; Sunitha, M. Development and validation of simvastatin by RP-HPLC method in bulk drug and pharmaceutical dosage forms. Am. J. PharmTech Res. 2013, 3, 370-377.

26. Varma, R.A.; Shanmukha-Kumar, J.V.; Reddy, M.S. Estimation of simvastatin and ezetimibe in combined tablet formulation by stability indicating high performance liquid chromatography. Pharm. Lett. 2015, 7, 204-212.

27. Oliveira, P.R.; Barth, T.; Todeschini, V.; Dalmora, S. Simultaneous liquid chromatographic determination of ezetimibe and simvastatin in pharmaceutical products. J. AOAC Int. 2007, 90, 1566-1572. [PubMed]

28. Sonali, R.; Pallavi, P.; Vittal, C. Development and validation of HPTLC method for the estimation of sitagliptin phosphate and simvastatin in bulk and marketed formulation. Int. J. Drug Dev. Res. 2012, 4, 292-297.

29. Palled, M.S.; Chatter, M.; Rajesh, P.M.N.; Bhat, A.R. Difference spectrophotometric determination of telmisartan in tablet dosage forms. Indian J. Pharm. Sci. 2006, 68, 685-686.

30. Ilango, K.; Kumar, P.S. Validated spectrophotometric methods for the simultaneous determination of telmisartan and atorvastatin in bulk and tablets. Pharm. Methods 2012, 3, 112-116. [CrossRef] [PubMed]

31. Nalwade, S.; Reddy, V.R.; Rao, D.D.; Rao, I.K. Rapid simultaneous determination of telmisartan, amlodipine besylate and hydrochlorothiazide in a combined poly pill dosage form by stability-indicating ultra performance liquid chromatography. Sci. Pharm. 2011, 79, 69-84. [CrossRef] [PubMed]

32. Jadhav, S.; Rai, M.; Kawde, P.B.; Farooqui, M. Simultaneous determination of telmisartan, amlodipine besylate and hydrochlorothiazide in tablet dosage form by using stability indicating HPLC method. Pharm. Sin. 2015, 6, 13-18. 
33. Kurade, V.P.; Pai, M.G.; Gude, R. RP-HPLC estimation of ramipril and telmisartan in tablets. Indian J. Pharm. Sci. 2009, 71, 148-151. [CrossRef] [PubMed]

34. Singh, S. Simultaneous estimation of telmisartan and ramipril in combined dosage form by using HPTLC. Pharm. Lett. 2012, 4, 509-514.

35. Ilango, K.; Kumar, P.S.S. Development and validation of stability indicating HPTLC and HPLC methods for simultaneous determination of telmisartan and atorvastatin in their formulations. J. Chem. 2013, 2013, 725385. [CrossRef]

36. Mehta, S.; Singh, S.; Chikhalia, K.; Mehta, P.; Dadhania, T. Determination of assay and uniformity of content of ramipril and telmisartan in their multiple dosage forms by a developed and validated supercritical fluid chromatographic technique. Anal. Methods 2014, 6, 7068-7074. [CrossRef]

37. Albero, I.; Rodenas, V.; García, S.; Sanchez-Pedreno, C. Determination of irbesartan in the presence of hydrochlorothiazide by derivative spectrophotometry. J. Pharm. Biomed. Anal. 2002, 29, 299-305. [CrossRef]

38. Erk, N. Three new spectrophotometric methods applied to the simultaneous determination of hydrochlorothiazide and irbesartan. Pharmazie 2003, 58, 543-548. [PubMed]

39. Kumar, J.S.P.; Annapurna, M.M. New spectrophotometric methods for the simultaneous determination of irbesartan and hydrochlorothiazide in combined dosage forms. Pharm. Methods 2015, 6, 120-125. [CrossRef]

40. Rane, V.P.; Patil, K.R.; Sangshetti, J.N.; Yeole, R.D.; Shinde, D.B. Stability indicating LC method for simultaneous determination of irbesartan and hydrochlorothiazide in pharmaceutical preparations. J. Chromatogr. Sci. 2010, 48, 595-600. [CrossRef] [PubMed]

41. Alanazi, A.M.; Abdelhameed, A.S.; Khalil, N.Y.; Khan, A.A.; Darwish, I.A. HPLC method with monolithic column for simultaneous determination of irbesartan and hydrochlorothiazide in tablets. Acta Pharm. 2014, 64, 187-198. [CrossRef] [PubMed]

42. International Conference on Harmonization (ICH). Validation of Analytical Procedures: Text and Methodology, Q2 (R1). November 2005. Available online: http:/ / www.ipqpubs.com/wp-content/uploads/ 2011/09/Q2_R1_Guideline.pdf (accessed on 17 August 2017).

43. Center for Drug Evaluation and Research, US Food and Drug Administration. Reviewer Guidance, Validation of Chromatographic Methods; FDA: Rockville, MD, USA, 1994. Available online: https://www.fda.gov/ downloads/Drugs/Guidances/UCM134409.pdf (accessed on 17 August 2017).

(C) 2017 by the authors. Licensee MDPI, Basel, Switzerland. This article is an open access article distributed under the terms and conditions of the Creative Commons Attribution (CC BY) license (http:/ / creativecommons.org/licenses/by/4.0/). 